Pak. j. sci. ind. res. Ser. A: phys. sci. 201558 (2) 59-65

\title{
Preparation and Characterisation of Some Transition Metal Complexes of Niacinamide (Vitamin $B_{3}$ )
}

\author{
Md. Mahmudul Hasan, Md. Elius Hossain, M. Ershad Halim and Md. Qamrul Ehsan* \\ Department of Chemistry, University of Dhaka, Dhaka-1000, Bangladesh
}

(received September 18, 2013; revised June 27, 2014; accepted July 9, 2014)

\begin{abstract}
Niacinamide forms metal complexes of general formula $\left[\mathrm{M}\left(\mathrm{C}_{6} \mathrm{H}_{6} \mathrm{~N}_{2} \mathrm{O}\right)_{2}\right] \mathrm{Cl}_{2}$; where $\mathrm{M}=\mathrm{Mn}$ (II), $\mathrm{Co}(\mathrm{II}), \mathrm{Ni}(\mathrm{II}), \mathrm{Cu}$ (II) and $\mathrm{Zn}$ (II) in the aqueous medium. The complexes were formulated by comparing the experimental and calculated data for $\mathrm{C}, \mathrm{H}, \mathrm{N}$ and metal. The prepared complexes were characterised by different physicochemical methods. The UV-vis, FTIR spectral analysis and thermo gravimetric analysis (TGA). TGA of these complexes have been discussed. Magnetic susceptibility values indicate that all complexes except $\mathrm{Zn}$ complex are paramagnetic in nature. The redox properties of the metal ions in the $\mathrm{Mn}, \mathrm{Cu}$ and $\mathrm{Zn}$ complexes have been discussed from the cyclic voltammetric studies. In all cases the systems are quasi reversible.
\end{abstract}

Keywords: niacinamide, magnetic susceptibility, metal complexes, thermo gravimetric analysis

\section{Introduction}

The vitamins are a disparate group of compounds. They have little in common either chemically or in their metabolic functions. Nutritionally, they form a cohesive group of organic compounds that are required in the diet in small amounts (micrograms or milligrams per day) for the maintenance of normal health and metabolic integrity (Bender, 2003). Considering the significant role of metal ions in vast number of widely different biological processes many scientists are working in the field of interaction of metals with different vitamins. A great deal of work has been done in the field of preparation and characterisation of metal-vitamin compounds (Mamun et al., 2011; Rahman et al., 2011; Ehsan et al., 2004; 2001; Haider et al., 1988; 1987).

Niacinamide named as vitamin $\mathrm{B}_{3}$ is one of the most important member of water-soluble vitamins (B-vitamins). Vitamin $B_{3}$ functions as coenzyme in oxidation and reduction reactions, functional part of NAD and NADP, role in intracellular calcium regulation and cell signaling. Vitamin $B_{3}$ deficiency causes pellagra, characterised by a photosensitive dermatitis, like severe sunburn, typically with a butterfly-like pattern of distribution over the face, affecting all parts of the skin that are exposed to sunlight. Similar skin lesions may also occur in areas not exposed to sunlight, but subject to pressure, such as the knees, elbows, wrists, and ankles. Advanced pellagra is also accompanied by a dementia or depressive psychosis, and

*Author for correspondence; E-mail: mqehsan@yahoo.com there may be diarrhoea (Bender, 2003). Studies of metalniacinamide complexes are therefore, very important from the physiological activity point in the living system.

The niacinamide is a 3-substituted derivative of pyridine. It has three donor atoms ( $2 \mathrm{~N}$ and $1 \mathrm{O})$. The coordination chemistry of niacinamide is important since there are possibilities to form variety of complexes with d-block metal ions. In this communication preparation and characterisation of niacinamide complexes of first row transition metals namely; $\mathrm{Mn}, \mathrm{Co}, \mathrm{Ni}, \mathrm{Cu}$ and $\mathrm{Zn}$ have been reported, all in the +2 oxidation state.

\section{Materials and Methods}

Analytical grade reagents (BDH and Aldrich) were used in all preparative and analytical works. Micro-analysis for $\mathrm{C}, \mathrm{H}$ and $\mathrm{N}$ were performed on an automatic micro-analyser in the Laboratory of Organic Structural Chemistry (Prof. Shinmyozu Lab.), Department of Molecular Chemistry, Graduate School of Sciences \& IMCE, Kyushu University, Japan. Metal content of the complexes were quantitatively determined by complexometric method. Chloride content of all the complexes were qualitatively tested by $\mathrm{AgNO}_{3}$ solution. The melting point of all the complexes were measured in a heating device with a thermometer, MELTEMP II Laboratory Devices made in USA. Infrared spectra of the complexes were recorded on a calibrated Fourier Transformation Infrared Spectrophotometer (Shimadzu FTIR IR prestige-21 S/N) in the range of 500$4500 \mathrm{~cm}^{-1}$ as $\mathrm{KBr}$ pellets at QC Department of Beximco 
Pharmaceuticals, Bangladesh. The electronic spectra of niacinamide and its complexes were recorded on a Shimadzu UV-visible recording spectrophotometer (UV$160 \mathrm{~A}$ ) in the wavelength range $200-1100 \mathrm{~nm}$ using nujol mull technique. The thermo gravimetric analysis of the complexes was carried out with a computer controlled TA-60WS thermo gravimetric analyser and TGA-50H detector made in Japan at Centre of Excellence, Dhaka University. The magnetic properties of the complexes were studied at ambient temperature on a magnetic susceptibility balance (Magway MSB Mk1 Sherwood Scientific Ltd., Cambridge, England). The cyclic voltammogram of the complexes were studied with Epsilon, a PC controlled potentiostat; developed by Bioanalytical Systems, Inc. USA.

Preparation and formulation. All the complexes were prepared by following a general procedure. In all cases 20 mmol niacinamide and $20 \mathrm{mmol}$ metal salt were dissolved separately in deionised water. These two solutions were filtered separately and mixed together. The resultant mixture was concentrated by heating carefully with moderately low flame in a Bunsen burner. Then the concentrated solution was allowed to cool at room temperature. The precipitate obtained was filtered, washed with water and dried over silica gel in a desiccator. All the complexes were stable in light and air. Preparation of the complexes are shown in scheme 1 .

The formulation of the complexes was done by comparing the experimental and calculated data for elemental analysis. The micro analytical data of C, H, N and M content in the prepared complexes are given below:

$\underline{\mathbf{A}}\left[\mathrm{Mn}\left(\mathrm{C}_{6} \mathrm{H}_{6} \mathrm{~N}_{2} \mathrm{O}\right)_{2}\right] \mathrm{Cl}_{2}$ : calcd, (\%): C, 38.91; H, 3.27; $\mathrm{N}, 15.13 ; \mathrm{Mn}, 14.85$.

anal Found, (\%): C, 38.22; H, 3.23; N, 14.86; Mn, 12.60 .

$\underline{\mathbf{B}}\left[\mathrm{Co}\left(\mathrm{C}_{6} \mathrm{H}_{6} \mathrm{~N}_{2} \mathrm{O}\right)_{2}\right] \mathrm{Cl}_{2}$ : calcd, $(\%): \mathrm{C}, 38.50 ; \mathrm{H}, 3.23$; N, 14.97; Co, 15.76 .

anal Found, (\%): C, 38.42; H, 3.24; N, 14.99; Co, 13.75.

C $\left[\mathrm{Ni}\left(\mathrm{C}_{6} \mathrm{H}_{6} \mathrm{~N}_{2} \mathrm{O}\right)_{2}\right] \mathrm{Cl}_{2}$ : calcd, (\%): C, 38.52; H, 3.24;

$\mathrm{N}, 14.98 ; \mathrm{Ni}, 15.70$.

anal Found, (\%): C, 37.62; H, 3.19; N, 14.69; Ni, 13.60.

D $\left[\mathrm{Cu}\left(\mathrm{C}_{6} \mathrm{H}_{6} \mathrm{~N}_{2} \mathrm{O}\right)_{2}\right] \mathrm{Cl}_{2}$ : calcd, (\%): C, 38.03; H, 3.20; $\mathrm{N}, 14.80 ; \mathrm{Cu}, 16.77$. anal Found, (\%): C, 37.95; H, 3.13; N, 14.78; Cu, 14.48. $\underline{\mathbf{E}}\left[\mathrm{Zn}\left(\mathrm{C}_{6} \mathrm{H}_{6} \mathrm{~N}_{2} \mathrm{O}\right)_{2}\right] \mathrm{Cl}_{2}$ : calcd, (\%): C, 37.85; H, 3.18; $\overline{\mathrm{N}}, 14.72 ; \mathrm{Zn}, 17.18$.

anal Found, (\%): C, 37.66; H, 3.27; N, 14.65; Zn, 14.96.

\section{Results and Discussion}

Metal complexes of niacinamide have been synthesised in the aqueous medium following a general procedure. The complexes have the general formula:

$\left[\mathrm{M}\left(\mathrm{C}_{6} \mathrm{H}_{6} \mathrm{~N}_{2} \mathrm{O}\right)_{2}\right] \mathrm{Cl}_{2} ; \mathrm{M}=\mathrm{Mn}(\mathrm{II}), \mathrm{Co}(\mathrm{II}), \mathrm{Ni}(\mathrm{II}), \mathrm{Cu}(\mathrm{II})$ and $\mathrm{Zn}(\mathrm{II})$

The complexes are soluble in water but insoluble in most of the common organic solvents. The physical appearance of the complexes are $\left[\mathrm{Mn}\left(\mathrm{C}_{6} \mathrm{H}_{6} \mathrm{~N}_{2} \mathrm{O}\right)_{2}\right] \mathrm{Cl}_{2}$ (light pink), [Co $\left.\left(\mathrm{C}_{6} \mathrm{H}_{6} \mathrm{~N}_{2} \mathrm{O}\right)_{2}\right] \mathrm{Cl}_{2}$ (orange), $\left[\mathrm{Ni}\left(\mathrm{C}_{6} \mathrm{H}_{6} \mathrm{~N}_{2} \mathrm{O}\right)_{2}\right] \mathrm{Cl}_{2}$ (yellowish green), $\left[\mathrm{Cu}\left(\mathrm{C}_{6} \mathrm{H}_{6} \mathrm{~N}_{2} \mathrm{O}\right)_{2}\right] \mathrm{Cl}_{2}$ (light green), $\left[\mathrm{Zn}\left(\mathrm{C}_{6} \mathrm{H}_{6} \mathrm{~N}_{2} \mathrm{O}\right)_{2}\right] \mathrm{Cl}_{2}$ (colourless). Melting point of the complexes are more than $200{ }^{\circ} \mathrm{C}$. The high melting point and the solubility nature of the complexes indicate that they are ionic in nature to some extent.

IR Spectral analysis. The IR spectral analysis confirm the formation as well as similar bonding nature of all the complexes. The IR absorption spectra of niacinamide and $\mathrm{Cu}$-niacinamide complex are compared in Fig. 1. The tentative assignments have been done on the basis of standard references (Silverstein et al., 2005, Banwell et al., 2003, Pavia et al., 2001) and presented in Table 1.

In all the complexes a strong peak at 3157 to $3203 \mathrm{~cm}^{-1}$ appears due to symmetric N-H stretching vibration. Asymmetric N-H stretching vibration appears at $~ 3319$ to $3402 \mathrm{~cm}^{-1}$. Whereas, for the ligand a strong broad peak at $3165 \mathrm{~cm}^{-1}$ and $3365 \mathrm{~cm}^{-1}$ was due to symmetric and asymmetric $\mathrm{N}-\mathrm{H}$ stretching vibration of $-\mathrm{NH}_{2}$ group, respectively. The change in sharpness and position of the peaks in the complexes with respect to that of ligand is due to the fact that the nitrogen participate in the coordination.

All the complexes absorb strongly at $\sim 1664$ to $1708 \mathrm{~cm}^{-1}$ due to $\mathrm{C}=\mathrm{O}$ stretching vibration. Strong sharp band appear at $\sim 1602$ to $1624 \mathrm{~cm}^{-1}$ due to aromatic $\mathrm{C}=\mathrm{C}$ stretching vibration. For ligand a strong peak at $1678 \mathrm{~cm}^{-1}$ and $1618 \mathrm{~cm}^{-1}$ are due to $\mathrm{C}=\mathrm{O}$ and aromatic $\mathrm{C}=\mathrm{C}$ stretching vibrations. At $\sim 1375$ to $1398 \mathrm{~cm}^{-1}$ all the complexes absorb
$20 \mathrm{mmol}$ metal salt dissolved in 10-15 mL deionised water
$20 \mathrm{mmol}$ of niacinamide dissolved in 10-15 mL deionised water

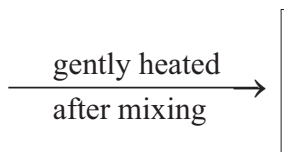

Solid precipitate of complexes were filtered out after cooling

Scheme 1. Preparation of complexes. 
Table 1. Comparison of IR bands of niacinamide and its complexes

\begin{tabular}{|c|c|c|c|c|c|c|c|}
\hline Compound & $\begin{array}{l}\mathrm{v}(\mathrm{NH}) \\
\text { str. } \\
(\mathrm{sym}) \\
\mathrm{cm}^{-1}\end{array}$ & $\begin{array}{l}\mathrm{v}(\mathrm{NH}) \\
\text { str. } \\
(\text { asym) } \\
\mathrm{cm}^{-1}\end{array}$ & $\begin{array}{l}\mathrm{v}(\mathrm{CH}) \\
\text { str. } \\
\text { aromatic } \\
\mathrm{cm}^{-1}\end{array}$ & $\begin{array}{l}v(\mathrm{C}=\mathrm{O}) \\
\text { str. } \\
\mathrm{cm}^{-1}\end{array}$ & $\begin{array}{l}\cup(\mathrm{C}=\mathrm{C}) \\
\text { str. } \\
\text { aromatic } \\
\mathrm{cm}^{-1}\end{array}$ & $\begin{array}{l}\mathrm{v}(\mathrm{NH}) \\
\text { bending } \\
\mathrm{cm}^{-1}\end{array}$ & $\begin{array}{l}\mathrm{v}(\mathrm{CN}) \\
\text { str. } \\
\mathrm{cm}^{-1}\end{array}$ \\
\hline Niacinamide & 3165 & 3365 & 2783 & 1678 & 1618 & 1576 & 1394 \\
\hline$\left[\mathrm{Mn}\left(\mathrm{C}_{6} \mathrm{H}_{6} \mathrm{~N}_{2} \mathrm{O}\right)_{2}\right] \mathrm{Cl}_{2}$ & 3203 & 3342 & 2365 & 1670 & 1622 & 1601 & 1375 \\
\hline$\left[\mathrm{Co}\left(\mathrm{C}_{6} \mathrm{H}_{6} \mathrm{~N}_{2} \mathrm{O}\right)_{2}\right] \mathrm{Cl}_{2}$ & 3196 & 3319 & 2754 & 1666 & 1602 & 1568 & 1396 \\
\hline$\left[\mathrm{Ni}\left(\mathrm{C}_{6} \mathrm{H}_{6} \mathrm{~N}_{2} \mathrm{O}\right)_{2}\right] \mathrm{Cl}_{2}$ & 3196 & 3367 & 2752 & 1664 & 1624 & 1605 & 1398 \\
\hline$\left[\mathrm{Cu}\left(\mathrm{C}_{6} \mathrm{H}_{6} \mathrm{~N}_{2} \mathrm{O}\right)_{2}\right] \mathrm{Cl}_{2}$ & 3157 & 3402 & 2360 & 1708 & 1605 & - & 1379 \\
\hline$\left[\mathrm{Zn}\left(\mathrm{C}_{6} \mathrm{H}_{6} \mathrm{~N}_{2} \mathrm{O}\right)_{2}\right] \mathrm{Cl}_{2}$ & 3184 & 3344 & 2762 & 1674 & 1603 & 1568 & 1375 \\
\hline
\end{tabular}

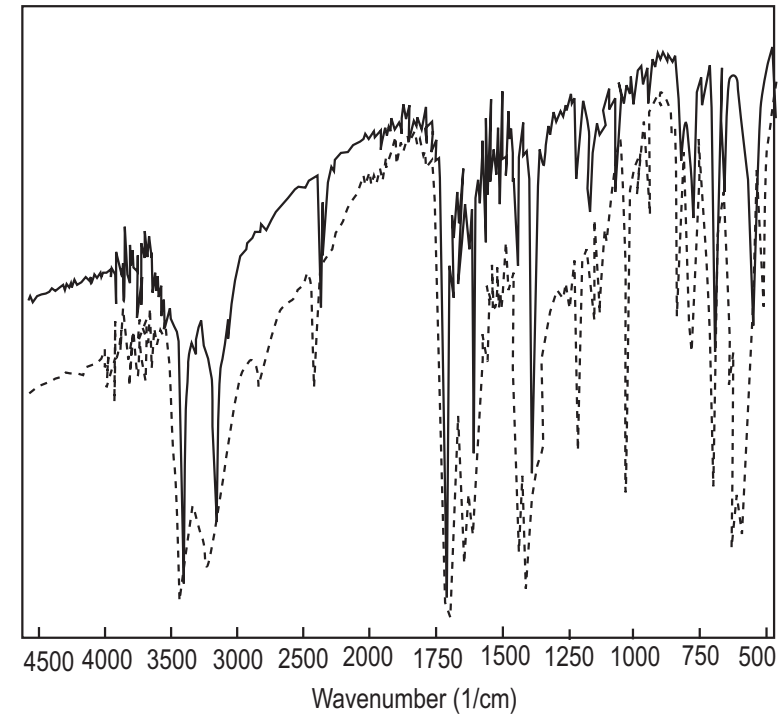

Fig. 1. Comparison of the FTIR spectra of (a) $\left[\mathrm{Cu}\left(\mathrm{C}_{6} \mathrm{H}_{6} \mathrm{~N}_{2} \mathrm{O}\right)_{2}\right] \mathrm{Cl}_{2}$ and (1) Niacinamide $\left(\mathrm{C}_{6} \mathrm{H}_{6} \mathrm{~N}_{2} \mathrm{O}\right)$ in the region 500 to $4500 \mathrm{~cm}^{-1}$.

due to C-N stretching vibration. A strong sharp peak at $1394 \mathrm{~cm}^{-1}$ appeared due to C-N stretching vibration for ligand. A sharp peak for aromatic $=\mathrm{C}-\mathrm{H}$ stretching vibration appears at 2360 to $2762 \mathrm{~cm}^{-1}$ in the complexes. The sharpness of the peaks due to $\mathrm{C}=\mathrm{O}, \mathrm{C}=\mathrm{C}$ and $\mathrm{CN}$ bands and their displacement with respect to that of ligand confirmed the formation of the complexes.

UV-vis spectral analysis. The electronic absorption spectra of the niacinamide complexes and their characteristic absorption bands with tentative assignments are presented in Fig 2 and Table 2, respectively. The assignments have been done on the basis of some standard references (Banwell et al., 2003; Pavia et al., 2001).

The $\mathrm{n} \rightarrow \sigma^{*}$ absorption bands due to the transition of nitrogen lone pair to the anti bonding orbital of $\mathrm{C}-\mathrm{N}$ bond

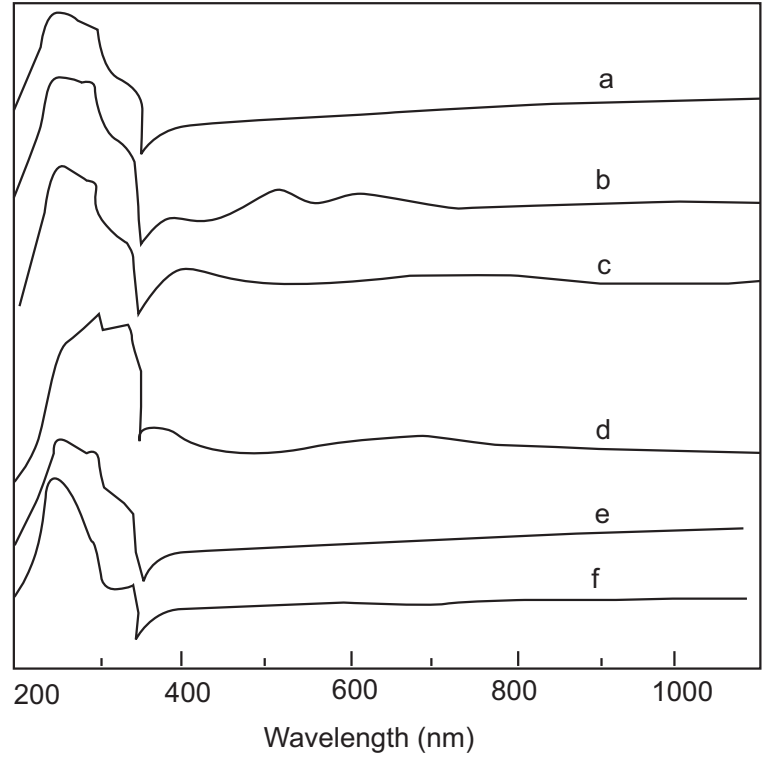

Fig. 2. The UV absorption spectrum in the region 200 to $1100 \mathrm{~nm}$ of (a) $\left[\mathrm{Mn}\left(\mathrm{C}_{6} \mathrm{H}_{6} \mathrm{~N}_{2} \mathrm{O}\right)_{2}\right] \mathrm{Cl}_{2}$ (b) $\left[\mathrm{Co}\left(\mathrm{C}_{6} \mathrm{H}_{6} \mathrm{~N}_{2} \mathrm{O}\right)_{2}\right] \mathrm{Cl}_{2}$ (c) $\left[\mathrm{Ni}\left(\mathrm{C}_{6} \mathrm{H}_{6} \mathrm{~N}_{2}\right.\right.$ $\left.\mathrm{O})_{2}\right] \mathrm{Cl}_{2}$ (d) $\left[\mathrm{Cu}\left(\mathrm{C}_{6} \mathrm{H}_{6} \mathrm{~N}_{2} \mathrm{O}\right)_{2}\right] \mathrm{Cl}_{2}$ (e) $[\mathrm{Zn}$ $\left.\left(\mathrm{C}_{6} \mathrm{H}_{6} \mathrm{~N}_{2} \mathrm{O}\right)_{2}\right] \mathrm{Cl}_{2}$ and (1) niacinamide $\left(\mathrm{C}_{6} \mathrm{H}_{6} \mathrm{~N}_{2} \mathrm{O}\right)$.

Table 2. Absorption bands of niacinamide and its complexes

\begin{tabular}{lllll}
\hline \hline \multirow{2}{*}{ Compound } & \multicolumn{4}{c}{ Absorption bands $\lambda_{\text {max }}(\mathrm{nm})$} \\
\cline { 2 - 5 } & $\mathrm{d} \rightarrow \mathrm{d}^{*}$ & $\mathrm{n} \rightarrow \pi^{*} \mathrm{n} \rightarrow \sigma^{*}$ & $\pi \rightarrow \pi^{*}$ \\
\hline Niacinamide $\left(\mathrm{C}_{6} \mathrm{H}_{6} \mathrm{~N}_{2} \mathrm{O}\right)$ & - & 343 & 300 & 250 \\
{$\left[\mathrm{Mn}\left(\mathrm{C}_{6} \mathrm{H}_{6} \mathrm{~N}_{2} \mathrm{O}\right)_{2}\right] \mathrm{Cl}_{2}$} & - & 340 & 298 & 263 \\
{$\left[\mathrm{Co}\left(\mathrm{C}_{6} \mathrm{H}_{6} \mathrm{~N}_{2} \mathrm{O}\right)_{2}\right] \mathrm{Cl}_{2}$} & 520,620 & 342 & 299 & 263 \\
{$\left[\mathrm{Ni}\left(\mathrm{C}_{6} \mathrm{H}_{6} \mathrm{~N}_{2} \mathrm{O}\right)_{2}\right] \mathrm{Cl}_{2}$} & 700 & 340 & 299 & 265 \\
{$\left[\mathrm{Cu}\left(\mathrm{C}_{6} \mathrm{H}_{6} \mathrm{~N}_{2} \mathrm{O}\right)_{2}\right] \mathrm{Cl}_{2}$} & 650 & 341 & 299 & 262 \\
{$\left[\mathrm{Zn}\left(\mathrm{C}_{6} \mathrm{H}_{6} \mathrm{~N}_{2} \mathrm{O}\right)_{2}\right] \mathrm{Cl}_{2}$} & - & 338 & 299 & 255 \\
\hline \hline
\end{tabular}


Table 3. Weight loss at different stages of TG analysis of niacinamide and metal-niacinamide complexes

\begin{tabular}{|c|c|c|c|c|c|}
\hline \multirow[t]{2}{*}{ Compound } & \multirow{2}{*}{$\begin{array}{l}\text { Sample } \\
\text { weight } \\
(\mathrm{mg})\end{array}$} & \multicolumn{2}{|l|}{ TG analysis } & & \multirow[t]{2}{*}{ Comments } \\
\hline & & $\begin{array}{l}\text { Transition } \\
\text { temp. }\left({ }^{\circ} \mathrm{C}\right)\end{array}$ & $\begin{array}{l}\% \mathrm{Wt} \\
\text { loss }\end{array}$ & & \\
\hline \multirow{3}{*}{\multicolumn{2}{|c|}{$\left[\mathrm{Cu}\left(\mathrm{C}_{6} \mathrm{H}_{6} \mathrm{~N}_{2} \mathrm{O}\right)_{2}\right] \mathrm{Cl}_{2}$}} & \multirow[t]{3}{*}{10.373} & $\begin{array}{l}32-60 \\
60-250\end{array}$ & $\begin{array}{l}6 \\
\text { No loss }\end{array}$ & $\begin{array}{l}\text { The weight loss may be due to loss of adhere water } \\
\text { No chemically bound water }\end{array}$ \\
\hline & & & $250-350$ & 57 & The weight loss may be due to loss of $\mathrm{CO}_{2}, \mathrm{HCl}, \mathrm{NH}_{3}, \mathrm{H}_{2}$ \\
\hline & & & $\begin{array}{l}350-580 \\
580-580 \\
(10 \text { min. }) \\
\text { Residue }=\end{array}$ & $\begin{array}{l}5 \\
6\end{array}$ & $\begin{array}{l}\text { It may be due to loss of } \mathrm{CH}_{4} \\
\text { The rest of the organic part may be lost }\end{array}$ \\
\hline
\end{tabular}

Table 4. Magnetic properties of the complexes of niacinamide

\begin{tabular}{|c|c|c|c|c|c|c|}
\hline \multirow[t]{2}{*}{ Compound } & \multirow{2}{*}{$\begin{array}{l}\chi_{\mathrm{A}} \\
(\mathrm{cgs}) \\
\mathrm{x} 10^{-3}\end{array}$} & \multicolumn{2}{|c|}{$\begin{array}{c}\mu_{\text {eff }} \text { BM } \\
\text { (at 300K) }\end{array}$} & \multirow{2}{*}{$\begin{array}{l}\text { No. of } \\
\text { unpaired } \\
\text { electron }\end{array}$} & \multirow[t]{2}{*}{$\begin{array}{l}\text { Config. } \\
\text { g. }\end{array}$} & \multirow[t]{2}{*}{ Inference } \\
\hline & & Found & Theo. & & & \\
\hline$\left[\mathrm{Mn}\left(\mathrm{C}_{6} \mathrm{H}_{6} \mathrm{~N}_{2} \mathrm{O}\right)_{2}\right] \mathrm{Cl}_{2}$ & 10.63 & 5.50 & $5.7-6.0$ & 5 & $d^{5}$ & Paramagnetic \\
\hline$\left[\mathrm{Co}\left(\mathrm{C}_{6} \mathrm{H}_{6} \mathrm{~N}_{2} \mathrm{O}\right)_{2}\right] \mathrm{Cl}_{2}$ & 11.47 & 5.20 & $4.3-5.2$ & 3 & $d^{7}$ & Paramagnetic \\
\hline$\left[\mathrm{Ni}\left(\mathrm{C}_{6} \mathrm{H}_{6} \mathrm{~N}_{2} \mathrm{O}\right)_{2}\right] \mathrm{Cl}_{2}$ & 3.598 & 2.94 & $3.0-3.3$ & 2 & $d^{8}$ & Paramagnetic \\
\hline$\left[\mathrm{Cu}\left(\mathrm{C}_{6} \mathrm{H}_{6} \mathrm{~N}_{2} \mathrm{O}\right)_{2}\right] \mathrm{Cl}_{2}$ & 1.09 & 1.62 & $1.7-2.2$ & 1 & $d^{9}$ & Paramagnetic \\
\hline$\left[\mathrm{Zn}\left(\mathrm{C}_{6} \mathrm{H}_{6} \mathrm{~N}_{2} \mathrm{O}\right)_{2}\right] \mathrm{Cl}_{2}$ & -ve & $0^{*}$ & - & 0 & $\mathrm{~d}^{10}$ & Diamagnetic \\
\hline
\end{tabular}

$*=$ The negative value of $\chi_{\mathrm{A}}$ indicates that the tube and sample have a net diamagnetism. In that case $\mu$ eff can be considered as zero.

appeared at $299 \mathrm{~nm}$ instead of $300 \mathrm{~nm}$ in niacinamide. The bands due to $\pi \rightarrow \pi^{*}$ transition in the metal complexes at $\sim 255-263 \mathrm{~nm}$ are somewhat broad and seem to be overlapped with the $\mathrm{n} \rightarrow \sigma^{*}$ bands. The $\mathrm{n} \rightarrow \pi^{*}$ transition bands in the complexes are observed in the region 338$340 \mathrm{~nm}$ whereas the ligand absorb at $343 \mathrm{~nm}$. The broad bands for the coloured complexes in the range of 520-700 $\mathrm{nm}$ were clearly due to the $\mathrm{d}$-d transitions which is absent for the complex with $\mathrm{d}^{10}$ system.

The presence of $\pi \rightarrow \pi^{*}, \mathrm{n} \rightarrow \pi^{*}$ and $\mathrm{n} \rightarrow \sigma^{*}$ bands in all the complexes indicate the presence of the functional groups of the parent ligand (e.g. $-\mathrm{C}=\mathrm{O},-\mathrm{NH}_{2}$ ). Shifting of the absorption bands in the complexes and appearing of a new band for $\mathrm{d}$-d transitions also indicate the probability of forming $\mathrm{M} \leftarrow \mathrm{L}$ coordination bonds in the complexes. Again the positions of the absorption bands also indicate the similar bonding pattern of the complexes.

Thermo gravimetric analysis. Thermo gravimetric TG curves of the complexes and the ligand are compared in Fig. 3 and the characteristic features of decomposition of $\left[\mathrm{Cu}\left(\mathrm{C}_{6} \mathrm{H}_{6} \mathrm{~N}_{2} \mathrm{O}\right)_{2}\right] \mathrm{Cl}_{2}$ are tabulated in Table 3 .

Thermo gravimetric analysis (TGA) reveals that niacinamide and its complexes are not accompanied by any chemically bonded water or water of crystallization. The pattern of the thermo grams also confirm the complexation between metal and niacinamide.

Magnetic properties. Magnetic moments of all the complexes were measured using a manual magnetic susceptibility balance. The measured values agree with the divalent oxidation state of the metals (Table 4).

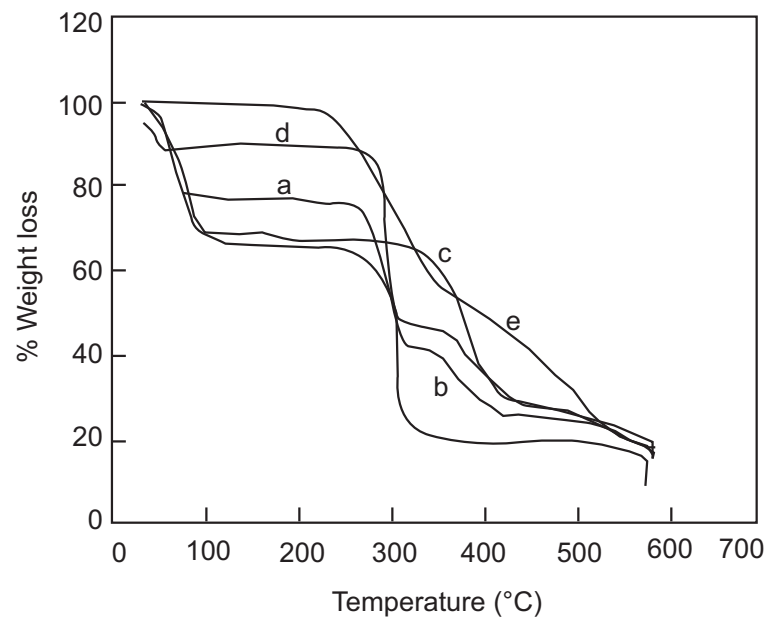

Fig. 3. TG curves of (a) $\left[\mathrm{Mn}\left(\mathrm{C}_{6} \mathrm{H}_{6} \mathrm{~N}_{2} \mathrm{O}\right)_{2}\right] \mathrm{Cl}_{2}$ (b) $\left[\mathrm{Co}\left(\mathrm{C}_{6} \mathrm{H}_{6} \mathrm{~N}_{2} \mathrm{O}\right)_{2}\right] \mathrm{Cl}_{2}$ (c) $\left[\mathrm{Ni}\left(\mathrm{C}_{6} \mathrm{H}_{6} \mathrm{~N}_{2} \mathrm{O}\right)_{2}\right]$ $\mathrm{Cl}_{2}$ (d) $\left[\mathrm{Cu}\left(\mathrm{C}_{6} \mathrm{H}_{6} \mathrm{~N}_{2} \mathrm{O}\right)_{2}\right] \mathrm{Cl}_{2}(\mathrm{e})\left[\mathrm{Zn}\left(\mathrm{C}_{6} \mathrm{H}_{6}\right.\right.$ $\left.\left.\mathrm{N}_{2} \mathrm{O}\right)_{2}\right] \mathrm{Cl}_{2}$ (1) Niacinamide $\left(\mathrm{C}_{6} \mathrm{H}_{6} \mathrm{~N}_{2} \mathrm{O}\right)$. 
The $\mu_{\text {eff }}$ values of the complexes demonstrate that all the complexes are sufficiently pure. The complexes of $\mathrm{Mn}$ (II), $\mathrm{Co}(\mathrm{II}), \mathrm{Ni}$ (II) and $\mathrm{Cu}$ (II) are high spin paramagnetic as suggested by their measured and standard magnetic moment values (Mamun et al., 2011, Rahman et al 2011). The $\left[\mathrm{Zn}\left(\mathrm{C}_{6} \mathrm{H}_{6} \mathrm{~N}_{2} \mathrm{O}\right)_{2}\right] \mathrm{Cl}_{2}$ complex is diamagnetic as the complex is $\mathrm{d}^{10}$ system. The deviation of magnetic moment value of copper ion may be due to some experimental errors.

Cyclic voltammetric studies. The redox behaviour of $\mathrm{Mn}(\mathrm{II}), \mathrm{Cu}(\mathrm{II})$ and $\mathrm{Zn}(\mathrm{II})$ in the coordinated and uncoordinated states were examined using cyclic voltammetric technique. All the solutions in the present study were prepared in freshly prepared $\mathrm{KCl}$ solution. The surface of the working electrode was polished with powdered alumina and rinsed thoroughly with deionised water before doing the experiments. The solution system was deoxygenated by purging with $\mathrm{N}_{2}$ gas and was homogenised by stirring with a magnetic stirrer. The cyclic voltammograms of the solution were recorded with respect to saturated $\mathrm{Ag} / \mathrm{AgCl}$ reference electrode.

$\mathrm{CV}$ studies of redox behaviour of $\mathrm{Cu}(\mathrm{II})$ in $\mathrm{CuCl}_{2}$ and ICu $\left(\mathrm{C}_{6} \mathrm{H}_{6} \boldsymbol{N}_{2} \mathrm{O}\right)_{2} / C_{2}$. The redox behaviour of $\mathrm{Cu}(\mathrm{II})$ in $\mathrm{CuCl}_{2}$ and $\left[\mathrm{Cu}\left(\mathrm{C}_{6} \mathrm{H}_{6} \mathrm{~N}_{2} \mathrm{O}\right)_{2}\right] \mathrm{Cl}_{2}$ were observed in $0.1 \mathrm{M}$ $\mathrm{KCl}$ using cyclic voltammetric technique on glassy carbon electrode within the potential window $1200-1300 \mathrm{mV}$ at room temperature. The voltammogram of the complex is compared with that of the free metal and niacinamide in Fig. 4.

The $\mathrm{CV}$ of $\mathrm{Cu}$ (II) in $\mathrm{CuCl}_{2}$ shows two cathodic peaks at potential $45.4 \mathrm{mV}$ and $-212.2 \mathrm{mV}$, and two anodic peaks at potential $241.0 \mathrm{mV}$ and $88.4 \mathrm{mV}$, respectively. In the metal complex, there were two cathodic peaks at potential $121.8 \mathrm{mV}$, and $-188.4 \mathrm{mV}$, and two anodic peaks at potentials $174.2 \mathrm{mV}$, and $55.0 \mathrm{mV}$, respectively. The voltammograms indicate that there were two oneelectron transfer processes i.e.,

The peak positions deviated noticeably in the complex system compared to that of free metal. However, the peak currents for both the anodic and cathodic peaks in the voltammogram of the complex are remarkably lower than that of metal salt.

Cathodic: $\mathrm{Cu}(\mathrm{II}) \stackrel{+\mathrm{e}^{-}}{\longrightarrow} \mathrm{Cu}(\mathrm{I}) \stackrel{+\mathrm{e}^{-}}{\longrightarrow} \mathrm{Cu}(0)$
Anodic: $\mathrm{Cu}(0) \stackrel{\mathrm{e}^{-}}{\longrightarrow} \mathrm{Cu}(\mathrm{I}) \stackrel{-\mathrm{e}^{-}}{\longrightarrow} \mathrm{Cu}(\mathrm{II})$

Scan rate variation. The cyclic voltammograms of $1 \mathrm{mM}$ $\left[\mathrm{Cu}\left(\mathrm{C}_{6} \mathrm{H}_{6} \mathrm{~N}_{2} \mathrm{O}\right)_{2}\right] \mathrm{Cl}_{2}$ at different scan rates are shown in Fig. 5. The current potential data, peak potential separation and peak current ratio of the voltammograms are recorded in Table 5.

The voltammograms of the metal complex at different scan rates expressed that with the increase of scan rate the peak currents for both cathodic and anodic peaks increases. Both the cathodic peaks shifted towards negative while the anodic peaks shifted towards positive direction with the increase of scan rate. The peak separation for the first pair of cathodic and anodic peaks increases with the increase of scan rate.

Randless-sevcick plot. A plot of peak current (first pair of peak) vs SQRT of scan rate (Fig. 6) for the metal complex showed that with the increase of scan rate peak, current for both cathodic and anodic peaks increases.

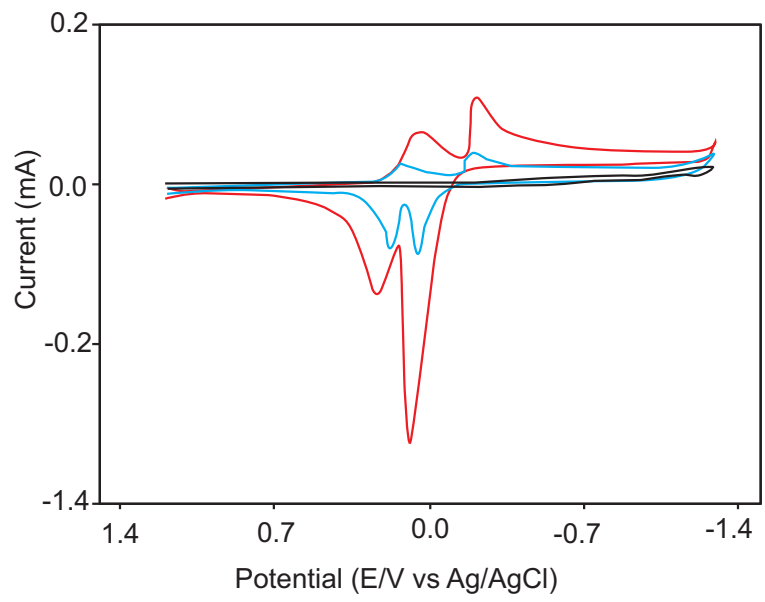

Fig. 4. $\mathrm{CVs} 1 \mathrm{mM} \mathrm{CuCl} 2,1 \mathrm{mM}\left[\mathrm{Cu}\left(\mathrm{C}_{6} \mathrm{H}_{6} \mathrm{~N}_{2} \mathrm{O}\right)_{2}\right] \mathrm{Cl}_{2}$ and $1 \mathrm{mM}$ niacinamide in $0.1 \mathrm{M} \mathrm{KCl}$ at 100 $\mathrm{mV} / \mathrm{s}$.

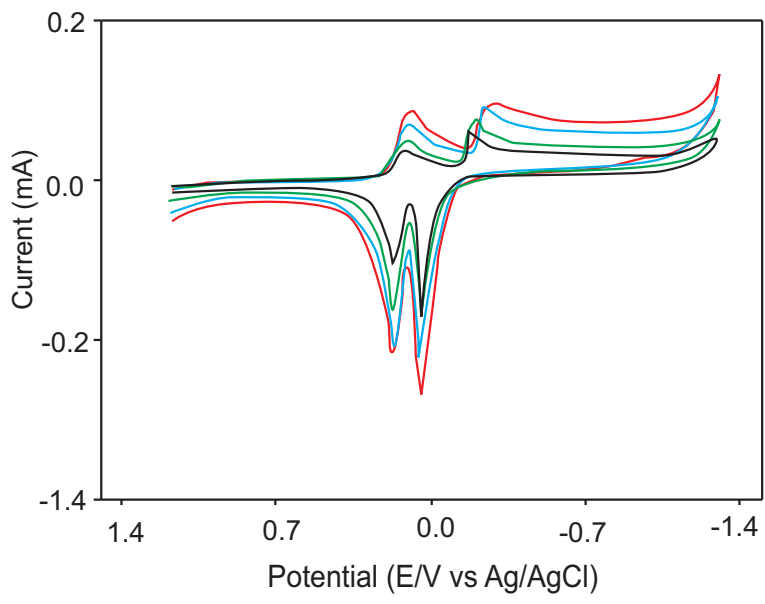

Fig. 5. $\mathrm{CVs}$ of $1 \mathrm{mM}\left[\mathrm{Cu}\left(\mathrm{C}_{6} \mathrm{H}_{6} \mathrm{~N}_{2} \mathrm{O}\right)_{2}\right] \mathrm{Cl}_{2}$ in $0.1 \mathrm{M}$ $\mathrm{KCl}$ at 300, 200, 100 and $50 \mathrm{mV} / \mathrm{s}$. 
Table 5. Current- Potential data, peak potential separation, peak current ratio of the voltammogram of $1 \mathrm{mM}$ $\left[\mathrm{Cu}\left(\mathrm{C}_{6} \mathrm{H}_{6} \mathrm{~N}_{2} \mathrm{O}\right)_{2}\right] \mathrm{Cl}_{2}$ in $0.1 \mathrm{M} \mathrm{KCl}$ at different scan rates

\begin{tabular}{llllllllllll}
\hline \hline $\mathrm{V}$ & $\mathrm{v}^{1 / 2}$ & $\begin{array}{l}\mathrm{E}_{\mathrm{pc} 1} \\
\mathrm{Volt}\end{array}$ & $\begin{array}{l}\mathrm{E}_{\mathrm{pc} 2} \\
\mathrm{Volt}\end{array}$ & $\begin{array}{l}\mathrm{E}_{\mathrm{pa} 1} \\
\mathrm{Volt}\end{array}$ & $\begin{array}{l}\mathrm{E}_{\mathrm{pa} 2} \\
\mathrm{Volt} \\
(-)\end{array}$ & $\begin{array}{l}\mathrm{i}_{\mathrm{pc} 1} \\
\mathrm{~mA}\end{array}$ & $\begin{array}{l}\mathrm{i}_{\mathrm{pc} 2} \\
\mathrm{~mA} \\
(+)\end{array}$ & $\begin{array}{l}\mathrm{i}_{\mathrm{pa} 1} \\
\mathrm{~mA}\end{array}$ & $\begin{array}{l}\mathrm{i}_{\mathrm{pa} 2} \\
\mathrm{~mA}\end{array}$ & $\begin{array}{l}\Delta \mathrm{E}_{\mathrm{p}} \\
\mathrm{Volt}\end{array}$ & $\begin{array}{l}\mathrm{i}_{\mathrm{pa} 1} / \mathrm{i}_{\mathrm{pc} 1} \\
(-)\end{array}$ \\
\hline 0.05 & 0.2236 & 0.1218 & 0.1693 & 0.1742 & 0.0502 & 0.0187 & 0.0341 & 0.054 & 0.075 & 0.0475 & 2.8877 \\
0.10 & 0.3162 & 0.1218 & 0.1884 & 0.1742 & 0.0550 & 0.0251 & 0.0393 & 0.081 & 0.089 & 0.0666 & 3.2271 \\
0.20 & 0.4472 & 0.1074 & 0.2361 & 0.1742 & 0.0597 & 0.0363 & 0.0457 & 0.105 & 0.113 & 0.1287 & 2.8926 \\
0.30 & 0.5477 & 0.0979 & 0.2838 & 0.1742 & 0.0597 & 0.0441 & 0.0504 & 0.109 & 0.133 & 0.1859 & 2.4716 \\
\hline \hline
\end{tabular}

$\mathrm{v}=$ scan rate; $\mathrm{v}^{1 / 2}=\mathrm{SQRT}$ of scan rate; $\mathrm{E}_{\mathrm{pc} 1}=$ cathodic peak potential for $1^{\text {st }}$ peak; $\mathrm{E}_{\mathrm{pc} 2}=$ cathodic peak potential for $2^{\text {nd }}$ peak, $\mathrm{E}_{\mathrm{pa} 1}=$ anodic peak potential for $1^{\text {st }}$ peak; $\mathrm{E}_{\mathrm{pa} 2}=$ anodic peak potential for $2^{\text {nd }}$ peak; $\mathrm{i}_{\mathrm{pcl}}=$ cathodic peak current for $1^{\text {st }}$ peak, $\mathrm{i}_{\mathrm{pc} 2}=$ cathodic peak current for $2^{\text {nd }}$ peak; $\mathrm{i}_{\mathrm{pa} 1}=$ anodic peak current for $1^{\text {st }}$ peak; $\mathrm{i}_{\mathrm{pa} 2}=$ anodic peak current for $2^{\text {nd }}$ peak, $\Delta \mathrm{E}_{\mathrm{p} 1}$ $=$ peak potential separation for $1^{\text {st }}$ pair of peak; $\mathrm{i}_{\mathrm{pal}} / \mathrm{i}_{\mathrm{pcl}}=$ peak current ratio for $1^{\mathrm{st}}$ pair of peak

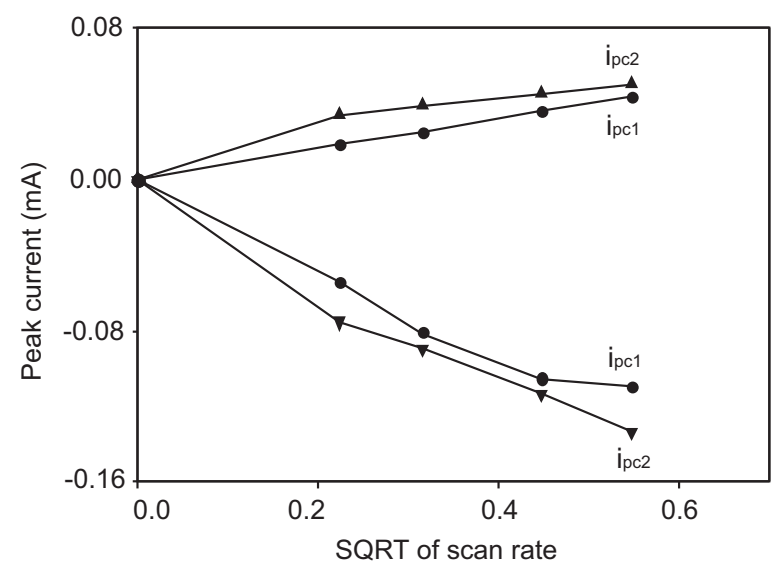

Fig. 6. Variation of peak current with SQRT of scan rate.

The shifting of the peaks in the complex compared to that of free metal confirmed the complexation of $\mathrm{Cu}$ (II) with niacinamide. The peak potential separation increases with scan rate due to slow electron transfer kinetics or ohmic potential (iR) drop. The linear increase of peak current with SQRT of scan rate revealed that the electrode process is diffusion controlled. The values of peak current ratio indicate that the process is quasi reversible (Akhtar et al., 2008; Shaikh et al., 2006; Wang 2006; Bard and Faulkner 2001; Brett and Brett, 1993).

Redox behaviour of the complexes $\left[\mathrm{Mn}\left(\mathrm{C}_{6} \mathrm{H}_{6} \mathrm{~N}_{2} \mathrm{O}\right)_{2}\right]$ $\mathrm{Cl}_{2}$ and $\left[\mathrm{Zn}\left(\mathrm{C}_{6} \mathrm{H}_{6} \mathrm{~N}_{2} \mathrm{O}\right)_{2}\right] \mathrm{Cl}_{2}$ were also studied. The $\mathrm{Mn}$-complex showed two pair of redox signals. The probable electron transfer processes are:

Cathodic: $\mathrm{Mn}(\mathrm{IV}) \stackrel{+\mathrm{e}^{-}}{\longrightarrow} \mathrm{Mn}(\mathrm{III}) \stackrel{+\mathrm{e}^{-}}{\longrightarrow} \mathrm{Mn}(\mathrm{II})$ Anodic: $\mathrm{Mn}(\mathrm{II}) \stackrel{-\mathrm{e}^{-}}{\longrightarrow} \mathrm{Mn}(\mathrm{III}) \stackrel{-\mathrm{e}^{-}}{\longrightarrow} \mathrm{Mn}(\mathrm{IV})$

The CV of $\left[\mathrm{Zn}\left(\mathrm{C}_{6} \mathrm{H}_{6} \mathrm{~N}_{2} \mathrm{O}\right)_{2}\right] \mathrm{Cl}_{2}$ showed one pair of redox signals. The probable electron transfer processes are:

$$
\begin{aligned}
& \text { Cathodic: } \mathrm{Zn}(\mathrm{II}) \stackrel{+2 \mathrm{e}^{-}}{\stackrel{-2 \mathrm{e}^{-}}{\longrightarrow}} \mathrm{Zn}(0) \\
& \text { Anodic: } \mathrm{Zn}(\mathrm{II})
\end{aligned}
$$

The $\mathrm{Mn}$ and $\mathrm{Zn}$ complexes behaved almost similarly to that of the $\mathrm{Cu}$-complex. In both the cases the electron transfer processes were diffusion controlled and quasi reversible.

\section{Conclusion}

(i) Niacinamide forms coordination complexes with $\mathrm{Mn}(\mathrm{II}), \mathrm{Co}(\mathrm{II}), \mathrm{Ni}(\mathrm{II}), \mathrm{Cu}(\mathrm{II})$ and $\mathrm{Zn}(\mathrm{II})$ in 2:1 ratio.

(ii) Weight losing pattern of all the complexes are similar indicating similar structure of the complexes.

(iii) All except $\mathrm{Zn}(\mathrm{II})$ produces paramagnetic complexes with the ligand.

(iv) The redox properties of the metal ions changes appreciably on complexation with niacinamide

\section{Acknowledgement}

The authors would like to acknowledge the support from Prof. Shinmyozu of the Laboratory of Organic Structural Chemistry, Department of Molecular Chemistry, Graduate School of Sciences \& IMCE, Kyushu University, Japan, for supplying the elemental analysis data of the samples.

\section{References}

Akhtar, H.M.N., Shaikh, A.A., Ehsan, M.Q. 2008. Cyclic voltammetric study of the redox behavior of $\mathrm{Fe}(\mathrm{II}) / \mathrm{Fe}(\mathrm{III})$ systems forming during the oxidation of $\mathrm{Fe}$ (II) complexes with saccharin and 1,10- phenanthroline. Russian Journal of Electrochemistry, 44: 1403-1408. 
Banwell, C.N., McCash, E.M. 1995. Fundamentals of Molecular Spectroscopy, pp. 84-88, 189-192, $4^{\text {th }}$ edition, McGraw-Hill International Limited, UK.

Bard, A.J., Faulkner, L.R. 2001. Electrochemical Methods Fundamentals and Applications, pp. 228-255, $2^{\text {nd }}$ edition, John Wiley \& sons, Inc., New York, USA.

Bender, D.A. 2003. Nutritional Biochemistry of the Vitamins, 512 pp., $2^{\text {nd }}$ edition, Cambridge University Press, UK.

Brett, C.M.A., Brett, A.M.O. 1993. Electrochemistry Principles, Methods and Applications, pp. 174191, Oxford University Press, New York, USA.

Ehsan, M.Q., Begum, S.M., Islam, S.M.S. 2004. Preparation and characterization of pyridoxine complexes of $\mathrm{Fe}(\mathrm{III}), \mathrm{Mo}(\mathrm{VI}), \mathrm{Cd}(\mathrm{II}), \mathrm{Hg}(\mathrm{II})$ and U(VI). Journal Saudi Chemical Society, 8: 251-256.

Ehsan, M.Q., Khatun, S., Quyser, M.A. 2001. Preparation and characterisation of pyridoxine complexes of $\mathrm{Mn}(\mathrm{II}), \mathrm{Co}(\mathrm{II}), \mathrm{Ni}(\mathrm{II}), \mathrm{Cu}(\mathrm{II})$ and $\mathrm{Zn}(\mathrm{II})$. Journal Saudi Chemical Society, 5: 59-65.

Haider, S.Z., Malik, K.M.A., Khan, M.S., Bakshi, P.K., Bhuiyan, A.A., Hursthouse, M.B. 1988. Preparation, characterization and properties of some metalthiamine compounds of general formula $\left(\mathrm{Cl}_{2} \mathrm{H}_{17}\right.$ $\left.\mathrm{N}_{4} \mathrm{OS}\right) \mathrm{MCl}_{3} \cdot 0.5 \mathrm{H}_{2} \mathrm{O}[\mathrm{M}=\mathrm{Co}(\mathrm{II}), \mathrm{Zn}(\mathrm{II})$ and $\mathrm{Cd}(\mathrm{II})$. Journal of Bangladesh Academy of Sciences, 12: 197-206.

Haider, S.Z., Malik, K.M.A., Bakshi, P.K., Bhuiyan, A.A., Khan, M.S., Hursthouse, M.B. 1987. Preparation, characterization and properties of the metal-thiamine compounds $\left(\mathrm{C}_{12} \mathrm{H}_{18} \mathrm{~N}_{4} \mathrm{OS}\right) \mathrm{CuCl}_{4}$ and $\left(\mathrm{C}_{12} \mathrm{H}_{18} \mathrm{~N}_{4} \mathrm{OS}\right)$ $\mathrm{MCl}_{4} \cdot \mathrm{H}_{2} \mathrm{O}[\mathrm{M}=\mathrm{Co}(\mathrm{II}), \mathrm{Zn}(\mathrm{II}), \mathrm{Cd}(\mathrm{II})$ and $\mathrm{Hg}(\mathrm{II})]$. Journal of Bangladesh Academy of Sciences, 11: 117127.

Mamun, M.A., Ahmed, O., Bakshi, P.K., Yamauchi, S., Ehsan, M.Q. 2011. Synthesis and characterization of some metal complexes of cystine: $\left[\mathrm{Mn}\left(\mathrm{C}_{6} \mathrm{H}_{10}\right.\right.$ $\left.\mathrm{N}_{2} \mathrm{O}_{4} \mathrm{~S}_{2}\right)$ ]; where $\mathrm{M}=\mathrm{Mn}(\mathrm{II}), \mathrm{Co}(\mathrm{II}), \mathrm{Ni}(\mathrm{II}), \mathrm{Cu}(\mathrm{II})$, $\mathrm{Zn}(\mathrm{II}), \mathrm{Cd}(\mathrm{II}), \mathrm{Hg}(\mathrm{II})$ and $\mathrm{Pb}(\mathrm{II})$. Russian Journal of Inorganic Chemistry, 56: 1972-1980.

Pavia, D.L., Lampman, G.M., Kriz, G.S. 2001. Introduction to Spectroscopy, pp. 26, 28, 357-386, $3^{\text {rd }}$ edition, Harcourt College Publisher, Fort Worth, New York, USA.

Rahman, K.L., Mamun, M.A., Ehsan, M.Q. 2011. Preparation of metal Niacin complexes and characterization using spectroscopic and electrochemical techniques. Russian Journal of Inorganic Chemistry, 56: 14361442.

Shaikh, A., Begum, M., Khan, A.H., Ehsan, M.Q. 2006. Cyclic voltammetric studies of the redox behavior of iron(III)-vitamin B6 complex at carbon paste electrode. Russian Journal of Electrochemistry, 42: 620-625.

Silverstein, R.M., Webster, F.X., Kiemle, D.J. 2005. Spectrometric Identification of Organic Compounds, pp. $75-108,7^{\text {th }}$ edition, John Wiley \& Sons, Inc., New York, USA.

Wang, J. 2006. Analytical Electrochemistry, pp. 29-40, $3^{\text {rd }}$ edition, John Wiley \& Sons, Inc., New York, USA. 